\title{
Partnership Model for Optimizing the Use of Village Funds
}

\author{
Mukhtar Sarman \\ Faculty of Social and Political Sciences, Lambung Mangkurat University, Banjarmasin, South \\ Kalimantan. 70123 \\ aMochtar_SAR@yahoo.co.id
}

\begin{abstract}
Since 2015, the Government has allocated village development funds in the form of Village Fund policies of IDR 20.7 trillion, then in 2016 it increased to IDR 46.9 trillion, and continues to increase in the following years. However, based on field research in a number of regions in Indonesia, it turns out that the use of Village Funds is not optimal, some of which have been proven wrongly targeted, not transparent in use, and not accountable in reporting. The aspect of planning activities and the quality of human resources implementing policies and coordination between parties that should play a role are still a major problem.

The PPP (Public-Private Partnership) model is actually intended for the development of large-scale projects, such as the construction of highways or seaports and airports. But by taking the substance of cooperation from the parties that each have strengths, the PPP model (and its variants) may be applicable in the use of Village Funds. Using secondary data analysts, the following article discusses the theoretical aspects of the advantages of the PPP model. This model is juxtaposed with cases of success in building the economic self-reliance of rural communities with the help of private parties and academics. It is assumed that the partnership model can be an alternative solution to further optimize the use of Village Funds in order to reduce poverty in rural areas.
\end{abstract}

Keywords: Village Fund, PPP Model, economic self-reliance

\section{Introduction}

In Indonesia, the village is the center of the problem of the welfare of the nation's life. This is not only related to demographic facts, where 51 percent of the population of this country lives in villages with all their dynamics (BPS, 2010), but also poverty problems related to income inequality and low economic productivity of the people, when compared to the level of income and productivity of the community urban. Quoting Kompas.com (3/29/2017), the percentage of rural poverty was recorded at 13.96 percent or almost double the percentage of the poor in the city by 7.7 percent. Other data showed that the centers of poverty and gap in Indonesia are in rural villages and regions in Eastern Indonesia. As many as 60.91 percent of the poor live in the village. The majority of them work in the agricultural sector, which is 49.9 percent (Kompas, 07/31/2018).

The final report of the 2015 Center for Socio-Economic and Agricultural Policy of the Agricultural Research and Development Agency shows changes in consumption patterns in the village. The results of the study said, the consumption of carbohydrate sources of food increasingly leads to finished food. The contribution of local food to the consumption of the village community is decreasing because the attractiveness of the business in the village, especially agriculture, continues to reduce. The profession as a farmer is increasingly being abandoned because his income is no longer attractive. More than 70 percent of farmers aged 40 years and over, even those over 50 years old are more than 40 percent, meaning that they are less productive. On the other hand, the conversion of agricultural land and plantations continues to occur. In the last 10 years, there have been several villages, especially in the suburbs, which experienced conversion of paddy fields over 100 hectares. The conversion generally occurs due to infrastructure development, residential areas, industries, and transportation infrastructure. Therefore, it is assumed that there needs to be special attention 
by the Government to address the problem of rural development, especially in the vulnerable groups.

The government, since 2015, has a commitment to pay special attention in the form of Village Fund policies to finance infrastructure development and village community empowerment activities. The political considerations of granting village funds are based on Law No. 6 of 2014 concerning Villages, and Government Regulation number 60 of 2014 concerning Village Funds. The number of villages in Indonesia is 74,958. Village funds that are intended to finance village development are determined to be sourced from the State Budget. By the Ministry of Finance, the Village Fund allocation in 2015 was set at IDR 20.76 trillion. This means that each village receives a fund allocation of around IDR 628 million per year. In 2016 the allocation of Village Funds in the Draft State Budget increased to IDR 46.98 trillion, then to IDR 60 in the 2017 fiscal year, with an allocation of around IDR 1 billion per village. The realization of the Village Fund budget in the 2015-2017 period was recorded at IDR 127 trillion, a not a little amount of funds to build villages.

The question is whether the Village Fund policy that comes from the APBN has been utilized properly? The next question is, does the Village Fund's policy have a positive impact in the form of reducing rural poverty? The following explanation is an example of cases to show the fact in the field that the use of the Village Fund is actually full of problems, besides indeed in some areas the Village Fund has proven to provide extraordinary benefits to the village community.

\subsection{The obstacle on administrative procedures}

The rules for the implementation of Village Fund usage in the first years are arguably not well understood by the implementing apparatus, especially the Village Head as the person in charge of the implementation, although over time the implementation rules have been continuously refined. In the first year of implementation, the use of village fund could not be well understood by the village apparatus, especially by the village apparatus who acted as the executor and the person in charge of the project (see for example Sarman, 2017; and Yoseph, 2018).

The Ministry of Villages, Development of Disadvantaged Areas, and Transmigration (hereinafter referred to as the Village Ministery) stipulates Ministerial Regulation number 5 of 2015 concerning the priority of using Village Funds. The regulation states that Village Funds are used to improve the welfare of rural communities and alleviate poverty through fulfilling basic needs, developing village facilities and infrastructure, developing local economic potential, and utilizing resources and the environment.

The evaluation results of the Ministry of Village, the 2015 Village Fund disbursement for East Lombok District for example, has been disbursed in excess of IDR 164 billion, which is the total Village Fund in all districts. (Cendana News, 12/16/2015). Reportedly 92\% of the funds are used to build infrastructure that builds the fishing industry. The use of these funds is in accordance with article 7 section C of Ministerial Regulation number 5 of 2015 which states that Village Funds can be used to support maritime and marine development as a form of village infrastructure and infrastructure development and the development of local economic potential. This use is also considered appropriate by looking at the conditions in East Lombok where the amount of fishing production continues to rise from 2009, although it had dropped in 2011 before rising until 2013 according to data from the Marine and Fisheries Service. Whereas in Sleman, Village Funds are used to build infrastructure such as irrigation facilities, dams, and inter-village roads as well as community empowerment through fish farming. Flexibility Village Fund Management makes the Village Fund that should be used for infrastructure can be used for other village programs such as livestock and so on.

Although at the macro level the use of the Village Fund is effective enough, but many aspects still need to pay attention by the Government as Village Fund providers. For distribution of the IDR 20 trillion in Village Funds issued by the Government in 2015, funds that entered the new village were IDR 16.5 trillion. In October, of the 16.5 trillion only IDR 7.1 trillion was distributed to villages from the Regency. This could occur due to village 
delays in preparing the Village Revenue and Expenditure Budget (APBDes). For example in Pekalongan, in October 2015 there were 19 villages that had not yet compiled their APBDes (Sofianto, 2017). In addition, there are some regions that despite the awareness of the village government to carry out and prepare accountability reports well but have not received village funds until December as in the Kulon Progo area.

From various reports, the allocation of Village Funds in 2016 had problems in the aspect of the time to received it. Many villages have just received Village Funds a few months before December. In Temanggung for example, some new villages received Village Funds at the end of October, whereas the time to use village funds was only until December. This makes development activities ineffective. Infrastructure development cannot be completed on time. Villages that have not yet received funds have made development using loans or debt from third parties. Starting village development with funds from debt is risky. At the next stage, the villages concerned are constrained to fulfill their obligations to submit a report on the use of funds in 2016, and as a result the 2017 funds cannot be disbursed until March 2017 (Metronew.com, 03/12/2017). Whereas for 2017, in Temanggung Regency funds amounting to IDR 207 billion were provided. The funds will be distributed to 266 villages. Thus, each village in Temanggung Regency should receive funds of IDR 800 million - IDR 1.5 billion. Because of similar problems, the second and third stage of 2018 Village Fund disbursement for 26 districts in Papua Province is threatened to be stopped (Kompas, 05/19/2018).

At macro level, regulation can be considered a problem in Village Fund allocations in 2015 and 2016. Lack of village apparatus knowledge about applicable regulations makes allocation of funds not run smoothly. Every time receive funds, the village apparatus must make a letter of accountability first, even though many village officials do not understand about this process. As a result there is fear of the village apparatus to use Village Funds (Atmaja and Saputra, 2017).

The news presented by Kompas Dayly (06/29/2018) reinforces the notion that the problem of administrative procedures for disbursing funds is still the main problem. It was stated that 45,816 villages had not received the Village Fund the second stage because the village was late in fulfilling administrative requirements, including preparing the APBDes. As a result, as much as IDR 14.7 trillion in Village Funds still deposited in the accounts of 264 Local Governments, even though the funds should have been channeled to villages. The cause of this problem is mainly due to the village government - with a capacity that is generally still limited - slow to meet administrative requirements. Recognizing the limited capacity of village officials, Yoseph (2018) suggested that project administration and budgets for Village Funds should be simplified and made easy. It is not the other way around, as is done by some regions which actually adds the requirements to disburse Village Funds. For example in Central Java, there are local governments that require the physical design of buildings by villages before the Village Fund is disbursed. Even though this requirement is clearly not easy and not all village officials have such capacity.

Potential misuse of Village Funds can be seen from the perspective of large budget management, but its implementation at the village level is not accompanied by the principles of transparency, participation, and accountability in political governance, development, and village finance. According to the results of a review of Indonesia Corruption Watch (ICW), in 2015 - 2017 cases of corruption in the village increased. In 2015, corruption cases reached 17 cases and increased to 41 cases in 2016. The surge more than doubled then occurred in 2017 with 96 cases. A total of 154 cases of corruption were found. Not all of the 154 corruption cases in the village sector above are village budget corruption. The number of cases with village budget objects reached 127 cases, of which there were 27 cases with village nonbudget objects or a total of $18 \%$ of the total cases. Cases with non-budget village objects such as illegal charges by village officials. While the object of corruption in the village budget includes corruption of Village Fund Allocation (ADD), Village Fund, Village Cash, and others.

ICW (2018) further explained that from the aspect of state losses, corruption in the village contributed to large losses. In 2015 the loss reached IDR 9.12 billion. In 2016, losses 
reached IDR 8.33 billion. Meanwhile in 2017, losses jumped to IDR 30.11 billion. The total state losses caused by corruption in the village sector reached IDR 47.56 billion, equivalent to the basic allocation of APBN funds for 77 villages. Various modes were carried out by corruption actors in the village, including budget misuse practices as many as 51 cases, embezzlement of 32 cases, fictitious reports with 17 cases, fictitious activities / projects of 15 cases, and budget inflations of 14 cases. One of the budget misuse modes involving Sukaresmi Village Chief, Cisaat District, Sukabumi Regency. He allegedly misappropriated the Village Fund and ADD for personal gain with a total amount of IDR 186,881,376.

Regarding the vulnerability of the Village Fund, it was abused, actually it was tracked earlier in the day by the KPK. In June 2015, the KPK revealed the potential for corruption in the Village Fund. The potential for corruption includes four aspects, namely regulatory and institutional aspects, governance aspects, supervision aspects, and aspects of human resources. From the regulatory and institutional aspects, incomplete implementation regulations and technical instructions constitute the potential for corruption in this Village Fund. From the governance aspect, the time frame of the village budget management cycle and the standard price unit for the benchmark for the village to prepare the APBDes that are not yet available is a potential for corruption. From the aspect of supervision, the effectiveness of the regional apparatus in conducting low supervision coupled with the lack of good public complaint channels is considered as potential corruption. From the aspect of human resources, there is an opportunity for facilitators to do corruption or fraud using the weaknesses of the village apparatus (KPK: Press Release, 06/12/2015). And it was proven, the KPK then determined five suspects in the Village Security Fund 'bribe' case in Dassok Village, Pamekasan. Bribes were given IDR 250 million from the Village Head of Dassok to the Head of the District Prosecutor's Office (Kajari) Pamekasan. The bribe was given so that the Kajari Pamekasan did not follow up on the reporting of an NGO to the Pamekasan Prosecutor's Office in connection with the alleged procurement corruption in Dassok Village that used village funds worth IDR 100 million (DetikNews, 02/08/2017).

Regarding the procedure error in the use of the Village Fund it may not be solely in the case of the executing apparatus, because the administration procedures for Village Fund management really tend to be complicated. There are at least five government regulations under the law, plus 13 ministerial-level rules (ministerial regulations) as the legal umbrella for the implementation of village fund management. For villagers, village officials are no exception, it is not easy to understand how to implement Village Fund governance correctly. The results of field studies indicate that the implementing apparatus in the village government, program assistants, and even program supervisor in the district, are not really ready to use Dana Desa accountably in accordance with the principles of project management (Utama, 2017; Syakriah, 2017; Sekarsita, 2017; Sarman, 2017; Sarman and Purwanto, 2017; Sarman and Wahid, 2017; Mushalli, 2017; Yoseph, 2018). It was as if to justify the facts presented by various news in the mass media, that all parties seemed to see the Village Fund as merely a "project" and that each person wanted to be involved in the distribution of the "project". Whereas what is meant by the Village Fund "project" is actually a basic capital to realize an independent village community. That is, rural communities who are advanced and empowered. People who are able to explore the potential sources of themselves and their village environment in order to have a maximum impact on their welfare.

\subsection{Success story of Using Village Funds and Poverty Reduction}

In addition to the grim news about the use of the Village Fund, a number of success stories in various regions can also be shown. At the very least, the Village Ministry claims that for three years since 2015 it has succeeded in improving the condition of 15,000 underdeveloped villages from the original number of 20,000 villages (Kompas, 07/17/2018). Other Government data stated that the use of the Village Fund had been used, among others, for the construction of around 124 thousand kilometers of village roads, 791 kilometers of bridges, and access to clean water of 38.3 thousand units. In addition, around 3,000 boat mooring units, 18.2 thousand PAUD (Early Childhood Education Programs) units, 5,400 Polindes (village maternity huts) units, 6,600 village market units, 28.8 thousand irrigation 
units, 11.6 thousand Posyandu (Maternal and Child Health Service) units, and around 2,000 reservoir units (CNN Indonesia (08/16/2018), quoted the President when delivering the 2019 RAPBN Financial Note Speech in front of the DPR RI Plenary Session).

Although the numbers are still limited, what the Kompas Daily reported serially in the "Village Innovation" column shows that a number of regions have succeeded in using Village Funds, perhaps surpassing the imagination of the Village Fund policy makers themselves. For example the success story of the people of Langgongsari Village, Banyumas, Central Java. The Langgongsari Village apparatus utilizes the Village Fund to transform abandoned village land into agrotourism and village business centers. They also strengthen Village Owned Enterprises (BUMDes) with four other businesses. For that achievement, the Village Head received an award from the Financial Services Authority (Kompas, 01/31/2018).

The success story was also experienced by the residents of Seketi Village, Balongbendo, Sidoarjo, East Java, who chose to maintain the bamboo woven (tampah) tradition, by evolving according to current market tastes. Using Village Funds, local village officials in 2016 agreed to establish BUMDes. BUMDes opens capital access for artisans by providing business loans of IDR 1 million - IDR 3 million. Crafters are free from moneylenders when they have alternative funding sources. The loan from BUMDes is light interest, only 1 percent per year and without collateral. BUMDes also expand the marketing network of craftsmen through the village market, specifically bamboo woven products. Now there are 25 craftsmen who still exist. One craftsman, Khosim, is able to produce 150-200 tampah per month. Assuming a selling price of IDR 10,000 per tampah, the turnover reaches IDR 2 million per month. From the turnover, artisans can reap a net income of IDR 1.5 million because the production costs are low because they only calculate the cost of shopping for bamboo bars (Kompas, 01/24/2018).

The use of Village Funds for productive economic purposes was also carried out by residents of Ciawigajah, Beber District, Cirebon Regency, West Java. These villagers use the Village Fund to process water from the spring into bottled water. Marketing is carried out by BUMDes. According to the Ciawigajah Village Head, if it goes according to plan, village income can be IDR 1.2 billion per year from the bottled water business. Even though, the Village Government also utilizes the Village Fund to develop the village into a center for sweet potatoes, with a production of 200 tons - 300 tons of sweet potatoes per year (Kompas, 03/28/2018).

The socio-economic approach in utilizing Village Funds has also been carried out by three Village Heads, namely Jomboran, Jimbung, and Krakitan Village in Klaten District, Central Java. These three villages that are geographically close together collaborate so that the environmental potential they have is increasingly developing through various innovations and enhancing human resources. What the village heads did was to develop a "desapolitan" area based on BUMDes, with the help of thoughts from a Professor of Gadjah Mada University (Kompas, 11/4/2018).

From the example case of the successful use of the Village Fund, it can be underlined that one of the main supporting factors is the BUMDes institution, in addition to the active participation of the community. The BUMDes need to be established in every village that wants to use the Village Fund to spur the village economy based on its local economic potential. Perhaps aware of this, the Ministry of Village then prioritized the development of 40 rural economic areas, spread in 60 districts, among others in the Provinces of Aceh, Banten and Central Sulawesi. Regions are determined based on the availability of natural resources and the commitment of the local government (Kompas, 11/11/2018).

The positive impact of the use of Village Funds for the development of village infrastructure, and the possible development of BUMDes-based village economic institutions, make the government claim that the level of rural poverty descrease. Citing BPS, as many as 60.91 percent of Indonesia's poor population live in villages, and 49.9 percent of them work in the agricultural sector. The BPS also noted that the Gini ratio of the rural population had decreased from 0.334 in 2015 to 0.320 in 2017 . However, there were still many doubts about the claims about the signifacance of poverty reduction and inequality in rural areas. First, inequality due to structural poverty in the form of permanent subsistence life patterns, 
isolation, and external dependence is still quite widely seen in a number of underdeveloped villages, despite the diminishing national proportions. Second, thousands of villagers living in Riau Islands Province, Bangka-Belitung, North and Southeast Sulawesi, East Nusa Tenggara, West Nusa Tenggara, Maluku and North Maluku, Papua and West Papua, as well as several other provinces with high poverty rates require policy affirmations, so as not to continue to be dogged by the problem of purchasing power and difficulty accessing basic needs (Kompas, 08/10/2018).

\section{Discussion}

Basically the Village Fund policy is a real potential power to build a village so that it can become a national economic foundation that involves local economic resources. The problem is, in the operational aspect, the Government seems to only work alone, and does not utilize other parties who also have the power of resources as partners. Even if we understand one of the concepts of development based on partnership, the Government can actually be greatly helped to do village development better and more effectively.

So far, the Government tends to only use human resources in the bureaucracy; even though private parties and universities have abundant resources. Giving trust to the village community to manage the Village Fund itself is actually praiseworthy, but perhaps it is not effective to develop rural economic potentials that require enablers who are able to create and think out the box. In the context of empowering all available resources, the partnership concept may be offered.

\subsection{Partnership concept}

Conceptually, the partnership term is the cooperation of two equal parties and its presence is complementary. But operationally it can mean work relationships in the form of coordination and collaboration (see for example Balloch and Taylor, 2002: 6). The partnership concept in its praxis can be aimed at working on large projects, such as highways, railroads, procurement of electricity, telecommunications, seaports and airports - which the Government cannot usually do (and financed) it self. When the financing of an infrastructure project turns out to involve a private consortium, it needs to be considered carefully, whether to choose a cooperative model in the form of a concession or better in the form of a BOT (Build-Operate-Transfer). The BOT model is not the only option, because there are other options, for example: BOT (Build-Operate-Transfer), or BOO (Build-Own-Operate) or even DBFO (Design-Build-Finance-Operate). All models of cooperation have advantages and disadvantages. Therefore, the policy makers are then required to consider the factors of profit and loss and the opportunity to manage risk from the chosen collaboration model: is the project possible to be implemented (possible), is it affordable (affordable), is it necessary, will it be acceptable, is it useful, whether worthwhile, and so on. That is what became known as the Public-Private Partnership model (see Budina, Brixi, Irwin, 2007).

Every country seems to have different rational reasons for adopting the PPP model (see Table 1). But for Indonesia, like it or not, one of the dominant factors is to utilize the resources (especially in the financing and technological aspects) owned by the private sector when the government is unable to do it on its own independently. For example for hold a toll road construction project. The after the New Order regime collapse it turns out that the Indonesian Government does not have enough funds to provide the infrastructure needed to support economic growth. Another fact is that the existing infrastructure is not a few who suffer damage and need repairs. Therefore, perhaps an applicative model of PPP is needed, "Indonesia version" and with its own operational terms.

The PPP concept is a term in English, what is the term in Indonesian? PPP can be translated as Public and Private Partnership - and perhaps it will be more honest if the intention is "Government and Private Collaboration" (KPS). Collaboration is indeed a phrase that can have a negative connotation when the intention is directed at an evil conspiracy; but in fact the term can be neutral in order to show the existence of cooperation between parties where the position of the parties cooperating is not equal. 
Table 1. Variations in Reasons for Choosing PPP

\begin{tabular}{|c|l|l|}
\hline No & Country & Reasons to do-PPP \\
\hline 1 & United States & To improve operational efficiency \\
\hline 2 & United Kingdom & To increase competition \\
\hline 3 & South Korea & To access new and proven technologies \\
\hline 4 & India & To create employment opportunities \\
\hline 5 & Thailand & To provide services not currently provided \\
\hline 6 & Philippines & To create transparent procurement \\
\hline 7 & South Africa & Mobilize additional invesment funds \\
\hline
\end{tabular}

Source: quoted from Parente (2006), in Sarman (2009: 23)

I intend to offer the term "collaboration" for the definition of partnership. The reason is that the collaboration between the Government and Private parties in the case in Indonesia is almost never equal (Sarman, 2009: 19). Sometimes the Government has more power; and at other times the private sector is more dominant. "Equality" degree of cooperation is rare between Government and Private parties because of various reasons and factors. One common phenomenon related to infrastructure development, especially in the case of infrastructure development in the Region. In that case the position of the Regional Government is too dominant and the private sector (contracting company) is often just an extension of the bureaucracy. Whereas in the case of national-scale infrastructure development projects and involving large private companies, precisely the role of the Government sometimes resembles mere security guards and must be shielded when confronting the reproach of the project repellent group.

In terms of the use of the term "collaboration", its relevance is more to the functional aspect, that the parties that are collaborating do not have to be equal because what is important is the achievement of goals maximally and the results are beneficial to all parties, in accordance with the contribution of their respective roles. That there is one party that tends to behave "exploitatively" does not need to be a problem as long as the rules of the game are clear. The point is: substantially no party involved in the collaboration may be harmed.

But in a theoretical reference, which is presented by various references, the concept of PPP or KPS is a matter of collaboration between the Government and the Private sector. The community is not mentioned in the collaboration at all. In fact, who is the user of the infrastructure built if not the community?

In its history, the role of the Government was indeed very dominant during the New Order era, as if only the Government was the only institution that had the competence to design, facilitate, and carry out all development projects, including infrastructure projects. With such a paradigm, even if there is a "private" institution that must be involved, the private institution in question must be under the umbrella of BUMN (State-Owned Enterprises) or Regional-Owned Enterprises (Regional-Owned Enterprises), so that in the end a state monopoly arises.

The change in the paradigm of KPS projects took place after the New Order when the Government made to a number of new rules that accommodate the role of the Private sector as a "partner" for the Government to build the country. The idea of KPS is clearly a new breakthrough because it increases the role and bargaining position of the private sector. However, referring to the practice of the PPP model in Indonesia so far, it seems that a mindset change is still needed to involve the participation of the community or community in the process of its activities. 


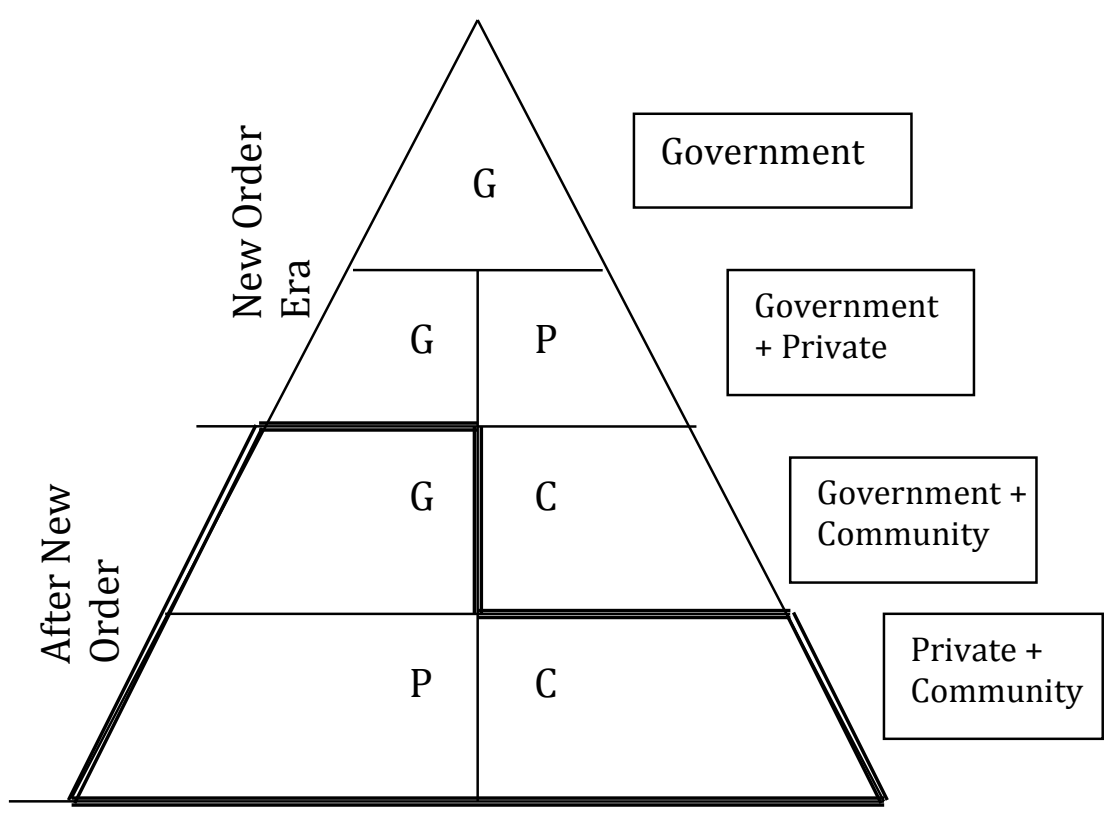

Figure 1. Government + Private + Community Collaboration Model

In other words, the concept of KPS should not be enough to be limited to the level of government relations and private, but also to be broader to reach the level of community involvement. In the case of Indonesia, the factor of community participation is assumed to be very important in supporting development, not least in infrastructure development projects. Procedurally, the idea may come from the Government (in the form of political will) and the idea is captured by the Private sector as an economic project opportunity; but when the project is operating, the community that is involved as the operator should be involved. Even if such a model is not fully applicable, at least the initial idea could have originated from the aspirations conveyed by the Community to the Government, and the Government handed over its technical problems to the Private Sector on the basis that the project was solely built to support the welfare of the community. Thus, the pattern of collaboration between parties will actually be more useful if it is a collaboration between the Government-PrivateCommunity (Figure 1).

In my view, if the community is involved from the stage of development planning, then the concept will be relevant to the mindset that citizens should not only be used as objects of development. Citizens must be the subject of development. Only with such an ideology will they feel "involved" and feel "responsible" for maintaining development output.

Community-based development is clearly a new breakthrough considering the typical development policies of Indonesia during the New Order period are too centralistic and top down oriented, in addition to tend to position citizens only as passive spectators. But how to formulate that strategy? The facts on the ground until now still illustrate that the "bottom-up" pattern as an anti-thesis of the "top down" pattern proved to be less effective - not least in the case of Village Fund use. Villagers generally interpret the means of utilizing the Village Fund from the perspective of the real "needs" that they feel now, not based on comprehensive planning to solve problems that may arise in the future. Examples such as using the Village Fund to build a village head's office, which is actually not too urgent compared to, for example, building access roads outside the village that had not been there so the village was isolated (see Yoseph, 2018).

\subsection{Forms of partnership application model that can be offered}

In practice, the concept of PPP (or KPS) can be aimed at any field. Let's take the case in Japan (Sarman, 2009). In Japan, the concept of PPP is more focused on the issue of PFI (Private Finance Initiative). This is motivated by reasons in the context of the role of the private sector that can help the Government overcome the lack of ability of the country's 
institutions to provide public services related to 'Life Cycle Cost', such as school buildings, hospitals, waste management, government offices, etc. (see for example Takao, 2007; also Akintoye, 2003). Therefore, the basic concept of PFI is a financing scheme for the provision of public facilities in order to support the improvement of public services. However, it should be understood that the position of the Private Company here is not just the executor of the project (through the SPC/Special Purpose Company mechanism), but can also be in the capacity as a lender (through a consortium company) which is an equity investor. In other words, the stakeholders involved in an infrastructure development project for public facilities are not limited to project implementers, but also funders, project consultants, supervisory committees, and even local residents (see Figure 2).

Therefore, in understanding the application of the PFI model, further understanding of the selection process is needed for the most preferred project bidders. In this context, the parties that play an important role are PFI Screening Committee — or if in Indonesia, perhaps the Procurement Committee - related to the feasibility assessment of the parties who want to take the opportunity to implement the project and what contract system is offered or will be agreed. The agreement that also needs to be set from the beginning is matters relating to risk allocation, whether to involve the insurance and how the agreement needs to be made with the funders. For the Lender, the agreement needed includes but not limited to: (1) establishment of security by Lender; (2) the statement of the political importance and the priority project; (3) confirmation of the fulfillment of PFI project contract; and (4) mutual reporting and meeting for the continuity of the project.

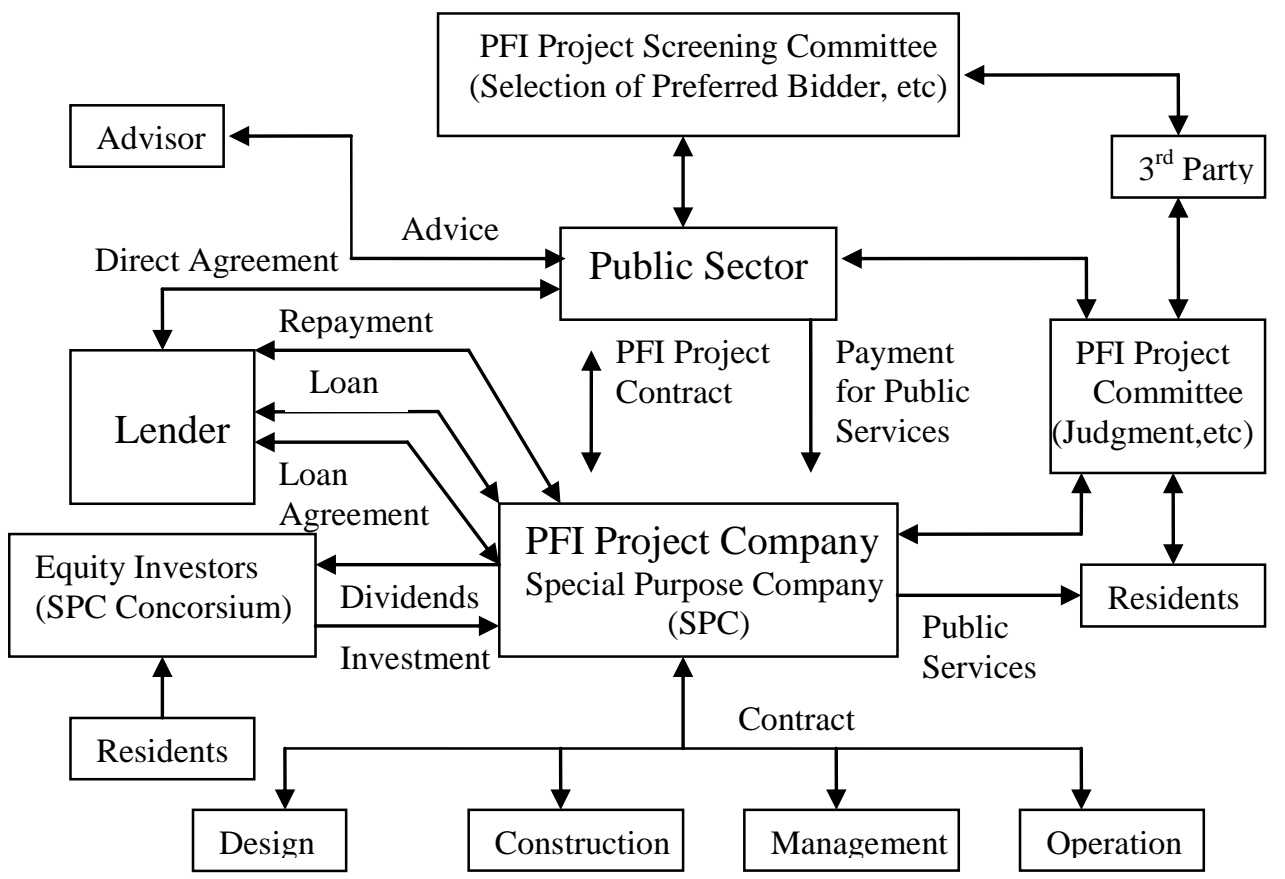

Figure 2. PFI-Based Parties' Collaboration Model.

In other words, there needs to be a guarantee that the infrastructure projects undertaken are safe from risks, including risks from default cases. That is why, in the PFI mechanism the role of the PFI Project Committee is also needed. The committee membership can be sourced from the public (residents), from the relevant government agencies, or representatives of the companies involved in the project, and even from third parties that are independent (such as a group of experts, public figures suspected of having relevant experience, and or a professional group like lawyers. Usually each party was represented by two people, and their task is: (1) To deal fairly and smoothly with possible arguments between Public Sector and PFI Project Company (SPC) during the execution of the project; (2) Judgment of service monitoring the 
outcome and contract termination; and (3) Assessment of the quality of assets transferred to the Public Sector at the end of the contract, etc. With this basis, the project can be monitored and how the mechanism for financing payments. The purpose of the monitoring was carried out so that the project implemented was guaranteed its sustainability and the guarantee to continue to maintain infrastructure when it was operated.

With such a detailed and the clear collaboration pattern like that, it does not mean that every company that has the competence to be involved as a project implementer can easily get the project. According to the rules of the PFI law in force in Japan, there are further criteria relating to the benchmarks of proposals from private companies that should be considered to be accepted. Every private company that wants to be involved is required to pay attention to the assessment aspects used by the Screening Committee, namely:

(1) The Administrator of Public Facilities, shall positively take appropriate measures necessary such as organizing acceptance, evaluation, notice and public announcement of proposals initiated by private enterprises;

(2) When a judgment was made to be appropriate to implement a proposal initiated by private enterprise, the same procedures as the PFI undertaking initiated by the Administrator of Public Facilities, shall have to be conducted for establishment of the Implementation Policy;

(3) For proposal of undertaking initiated and proposed by private enterprise, if it happens that the establishment of the Implementation Policy could not be realized within a considerable period of time, the results of such judgment and its reasoning shall have to be notified as soon as possible to the party proposed such undertaking. Further, an outline of such proposed undertaking, a summary of results of judgment by the Administrator of Public Facilities etc. and its reasoning shall have to be opened to public in an appropriate way at appropriate timing.

According to Shinohara (1998), the emergence of the idea of a PFI-based development financing model is inseparable from the impact of public administration reform in the provision of social infrastructure and public services that occur in Japan. Initially, public administration reform tended to adopt what was practiced in the United Kingdom; but because the socio-political conditions were not exactly the same, there were several policy modifications.

According to Yajima and Araki, ${ }^{1}$ there was indeed a misunderstanding regarding the concepts and applications of the PFI model in Japan. These misunderstandings, among others, relate to the issue that when PFI is taken as a policy, government funds do not need to be used; and private companies involved in the PFI project will not fall bankrupt; while small businesses (SMEs) cannot possibly participate in it. In fact, PFI is actually not suitable to be applied with conventional business approaches because the philosophy embodied in the PFI model is how to get support to provide better public services because of the active role of the private sector. Short-term benefits are not the objectives to be achieved in the PFI model. The reason is, one of the things that is less profitable in the PFI model is the costs that must be incurred for a number of agreements with the parties. For a number of people who are part of the parties, the adoption of the PFI model may still be a trial and error. namely:

There are 5 things that need to be understood as "facts" if you want to apply PFI,

(1) Provision of public services and low quality; in the sense that public services have been so low in quality that they require new breakthroughs (by involving competent private parties) to obtain improved quality of public services and at the same time reduce unnecessary operating costs.

1 Yuuichiro Yajima and Takayuki Araki are Project Management consultants at Pacific Consultants Co., Ltd (PCKK). Their opinion in this article is an excerpt from their presentation at the ID-PPP TOT training program at Miyazaki University, entitled "Basic Points and Facts of Japan PFI". 
(2) The role of administrative reform in public services; in the sense that traditionally there are a number of activities that should be private sector work but are carried out by the government; and that (in the future) must be reformed in accordance with the duties of each function, although its nature continues to prioritize the importance of the cooperation of the parties.

(3) Stimulating the economy through creating opportunities for private business; in the sense that the involvement of the private sector will improve the quality of public services (which are the responsibility of the Government) and at the same time reduce unnecessary operating costs.

(4) Reduced speed of building construction; in the sense that the construction sector be processed by the private sector often experience the risk of delays from the schedule that has been designed, but by involving them in the planning of the expected schedule it will reduce the risk.

(5) Smoothing of fiscal spending in local government finances improve; in the sense that the cost of research designs to repair and maintain public facilities is quite expensive and often unpredictable; and therefore in order to reduce the costs that must be borne by the government, the risk should be transferred to the private sector.

Therefore, it is necessary to understand the fundamental function of PFI, namely how to manage the cost of building a support facility Life Cycle Cost that the based on the principles of Administrative Reform, namely:

(1) From "Construction of Public Facilities" to "Provision of Public Services" (Meanings of Public Works):

a) From specification orders to performance specification orders (Define the contents of public services by required standard);

b) From construction works to integrated business system including design, construction, maintenance and operation;

c) From construction cost competition to comprehensive evaluation system (Total score of cost and performance).

(2) Lifecycle Cost Management:

a) Improvement of efficient and effective infrastructure and provision of good and low-cost public services to people (Cost reduction);

b) Promotion of efficiency by performance specification orders (Cost reduction);

c) Integrated business system including design, construction, maintenance and operation (Cost reduction);

d) Promotion of efficiency by prolonged single-year contracts to long term contracts (Reduction of direct cost and indirect cost);

e) Promotion of efficiency by integrating maintenance (Operation management) (Reduction of labor costs);

f) Risk transference (Cost reduction)

g) Utilization of private insurance (Cost reduction);

h) Energy management (Cost reduction).

(3) Effective use of Administrative Assets:

Local public authorities may lend administrative assets to selected businesses, if recognized necessary, disregarding the regulation local government laws. (PFI Law, the eleventh article, Lending out of administrative assets).

In the Indonesian context, practices like in Japan may still be many obstacles. Like it or not, in Indonesia the behavior of the private sector tends to still show itself as a "contractor" from government projects that are still dominant. In addition, the general public also still cannot appear as subjects with an interest in development, and therefore are not involved actively for participating since the project planning stage. 


\subsection{The context of empowerment and revitalizing the role of the community}

Within the framework of the partnership concept, it is relevant to talk about village community empowerment programs? The answer is, why not? The weakness of the use of the Village Fund so far is because it focuses on infrastructure development, and it does not touch the issue of empowerment. Policymakers in the Central Government may see a backwardness in the village (read: poverty) because the village tends to be isolated. That may be true. But when discussion be focused on the efforts to prosper the people in rural areas, inevitably the problem of empowering rural communities should be prioritized.

Referring to the research of Sarman et al (2008), community empowerment programs can be directed at utilizing local economic resources. Each sub-district area, at least, certainly has local economic resources that can be relied upon to become superior product. Some one tend optimistic that even if each village is unearthed its potential, undoubtedly has economic advantages, so the term "one village one product" (OVOP) applies - like the case of superior product development in Oita Prefecture, Japan. However, I am one of those people who are not very optimistic about the opportunity from one village only, and therefore interpreting it further becomes "one district one product" (ODOP) - like the case of superior product development in Uttar Pradesh, India. In fact, not every village in Indonesia has superior resources with high economic value. Conversely, several villages maybe at as having the same resources to be sold outside the region as superior product with competing product prices and quality, such as Medan's citrus-producing villages, or Papua coffee, and so on.

As a comparison, once again it's good to see success stories in Japan. In general, projects providing PFI-based public facilities may be somewhat sterile from community intervention. This assumption is probably not wrong if the problem is seen from the infrastructure planning process and how the financing is needed to make it happen.

However, there are three things why community members, and specifically certain communities, are very important in supporting the existence of a public infrastructure development project. First, the function of infrastructure is sometimes very dependent on community participation, such as infrastructure related to the municipal waste management system. Second, public facilities need care, and in this case certain community groups can contribute, such as city park infrastructure. Third, increasing the economic value of an infrastructure development project will sometimes be more significant when a particular community is involved in its management operations.

In Miyazaki, Japan, several infrastructure development projects can be found facilitated by the PFI model but it is even more valuable when local communities are involved in the operation of their use. One example of a community-based PFI model is the "Nichinan Coast Kirameki-line" project. The project was designed with the intention of developing tourist areas in the Nichinan region which are famous for its coastal potential. The goal is to be able to invite as many tourists and tourists to be satisfied with a number of attractions given by local residents. Therefore, the strategy was then designed to create a beautiful, friendly and healthy tourist area, there are historical links and myths.

This pattern of cooperation developed in the "Nichinan Coast Kirameki-line" project involves three main actors, namely: academics (in this case Miyazaki University) who are tasked with designing the landscape of a tourist area; industry circles, covering 41 private organizations; and the Government, both central and regional governments. The parties were then designed to collaborate with the local resident (see Figure 3).

The collaboration of the parties is designed in such a way as to complement each other. The Government, in accordance with its capacity and authority, is asked to provide a role in the construction of road facilities. Meanwhile, the volunteers called "Michimori", gave a touch of beauty to the environment around the road built by the government. In a pattern of cooperation called "Joint flower planting projects among communities", local residents voluntarily work together to plant cooperatives along the roadside to tourist areas with diverse flower plants, even to the center of tourist sites; and they have done it from 2005 to 2008. As a complement to community activities, they also take care of the forest around the tourist sites to support a design called "SEAGAIA". 


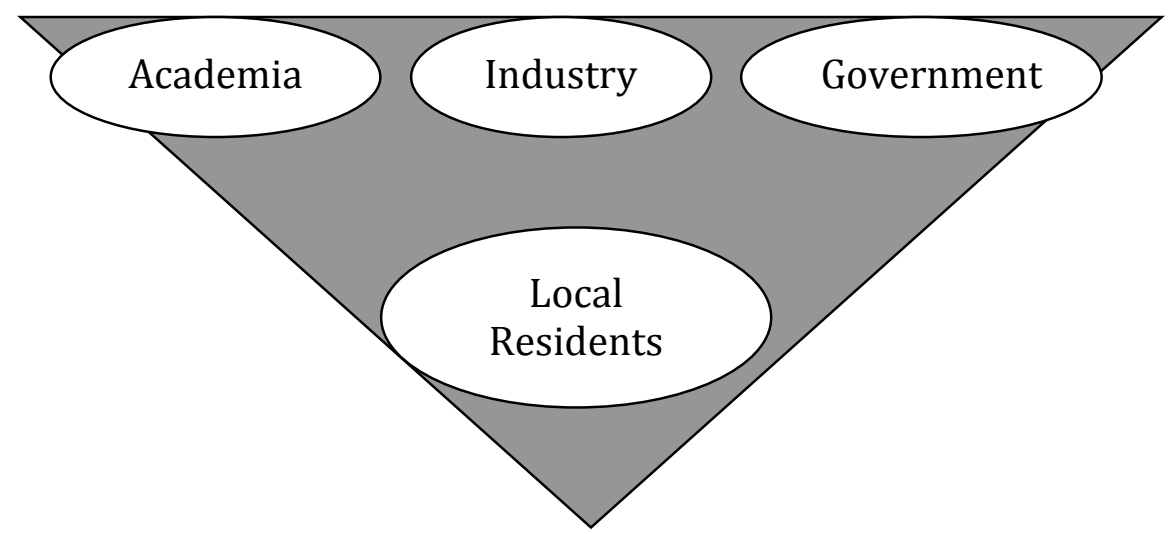

Figure 3. Partnership for Nichinan Coast Kirameki-line.

(Source: Tanigoshi, 2009).

"SEAGAIA's Planning" is a program design for tourists who are directed to visit a number of unique tourism objects, such as "Udoyama Excursion" (with the main object of sea catch, shrimp), "Aburatsu Port and Hori River Story" (with the main object, exploring river), and "Tour of Obi Castle Town" (with the main object riding on rickshaw (traditional pedicabs that are haunted by humans) around the tourist sites), or visiting the location of pine forests which sometimes become an introduction to the natural environment of students and students. Tourists are also allowed to visit historic attractions, such as Jurakudai palace and a samurai school (Shintoku Clan School). Even by the local government, there is a unique tourist location in the form of "Dream Bridge" (Yumehashi) in the center of Nichinan, a wooden bridge with very beautiful architecture, which is deliberately built with mythical spells that it is a legendary proof of a prince's love for the daughter he loves.

According to my observations, what is presented by the Nichinan Regional Government to develop tourism objects is not extraordinary if for comparison it is a tourist attraction spread in Yogyakarta for example. Various tourism objects in Yogyakarta are perhaps far more interesting and unique. The difference is, maybe in terms the tourism management pattern of. In Nichinan, there are no tourist locations that are subject to entrance fees. There is no vehicle parking fee. Even though the cost of infrastructure development it should be very large. Even if there are things that like "business", then the they business is souvenirs and a number of restaurants that provide a variety of Japanese specialties with prices that are "indeed expensive" for Indonesian people.

\section{Conclusion}

Village development policy is not perfect and needs further improvement. Village Fund Policy, as one of the Government's strategies to carry out Indonesia's development from the periphery, aims to realize an independent and dignified village. Therefore the point is how to build humans living in the countryside. However, in practice, the Village Fund policy tend not support community empowerment directly. First, because the Village Fund, in accordance with the allocation of its allocation all this time, focuses more on infrastructure development. Second, after the infrastructure project is completed, management of human resource development is often forgotten. In fact, the aspect of human resource development is more decisive in increasing the level of welfare of villagers.

The purpose of introducing a partnership model or collaboration in the use of Village Funds is actually intended so that these funds provide more outcomes for the community, so that rural communities can become independent. That the PPP or KPS or PFI model is not always in accordance with the conditions of the problem and the village environment, does not mean that the model offered in general must then be rejected. The partnership choice models must indeed be modified. It is the same as the OVOP or ODOP choice model to 
develop the rural economy based on existing local potential. Best practice from the implementation of certain models does require a pilot project first. However, waiting for the results of the pilot project is not an option, because the Government is now racing against time to get the best results from the use of effective and accountable Village Funds. Perhaps to find best practices in various regions, it is better if examples of success in various regions in using Village Funds for increase the role of BUMDes, are disseminated to other regions to be role models.

\section{References}

Agro Enterprise Center-FNCCI, 2012. Balancing Economic Growth One District Product: Local Employment Income Generation \& Food Security. (Federation of Nepalese Chambers of Commerce and Industry, Kathmandu).

Akintoye, Akintola, Matthias Beck, and Cliff Hardcastle (eds), 2003. Public-Private Partnerships: Managing Risks and Opportunities. (Blackwell Science Ltd, Oxford).

Atmadja, Anantawikrama Tungga dan Komang Adi Kurniawan Saputra, 2017. Pencegahan Fraud Dalam Pengelolaan Keuangan Desa. Jurnal Ilmiah Akuntansi dan Bisnis, Vol. 12, No. 1, Januari 2017.

Balloch, Susan \& Marilyn Taylor (eds), 2002. Partnership Working: Policy and Practice. (The Policy Press, Bristol, UK).

Budina, Nina, Hana P. Brixi, Timothy Irwin, 2007. Public-Private Partnership in the New EU Member States: Managing Fiscal Risk. (The World Bank, Washington DC).

Dahlquist, Julie R. and Richard J. Bauer, Jr, 2012. Identifying Profitable Gaps for Trading. (FT Press, New Jersey).

Hirohata, Nobuo, 2013. "One Village One Product movement in Laos". International Journal of Engineering Innovation and Management (3).

ICW, 2018. Outlook Dana Desa 2018 Potensi Penyalahgunaan Anggaran Desa di Tahun Politik. (Indonesia Corruption Watch, Jakarta).

Mushalli, Fahtul, 2017. Implementasi Dana Desa dalam Perencanaan dan Penganggaran Pembangunan Desa. (Tesis pada Program Magister Sains Administrasi Pembangunan Unversitas Lambung Mangkurat, Banjarbaru).

Kalia, Shalini et.al. (ed), 2015. Promoting Socio-Economic Development through Business Integration. (Business Science Reference, Hershey PA, USA).

Korten, David C., 1987, Community Management. (Kumarian Press, Westaharford, Connecticut).

Kurokawa, Kiyoto, Fletcher Tembo and Dirk Willem te Velde, 2010. Challenge for the OVOP Movement in Sub-Saharan Africa: Insights from Malawi, Japan and Thailand. JICA-RI Working Paper No. 18 June. (JICA Research Institute. Shinjuku-ku).

Li, Ning \& Fred R Schumann, 2013. "The One Village One Product (OVOP) Model and Economic Development on Guam". Journal of Economics and Economic Education Research, Volume 14, Number 3.

Malik, Hermen, 2015. Bangun Industri Desa: Selamatkan Bangsa. (IPB Press, Bogor).

Matsuoka, Kyomi, 2016. "A Comparative Analysis of the OVOP/OTOP Adminstration in Japan and Thailand". Journal of International OVOP Policy. Vol. 2. (International OVOP Policy Association/IOPA).

OECD, 2015. A New Rural Development Paradigm for the 21 $2{ }^{\text {st }}$ Century: Toolkit for Developing Countries. (OECD Publishing, Paris).

Ohaya, Oscar O., George Misigah, and Caroline Kinyanjui, 2015. "One Ville One Poruct (OVOP) - Regional Sustainable Development in Kenya". International Journal of Science and Research (IJSR), Volume 4 Issue 1, January.

Prasad, Shri Ranvir, et.al., 2018. Empowering Uttar Pradesh. (Uttar Pradesh Government, India).

Research \& Policy Department BCCI, 2015. Blueberry Cultivation In Bhutan: An Opportunity. Bhutan Chamber of Commerce \& Industry, Thimphu, Bhutan. 
Rozaki, Abdur, dkk, 2016. "Mengembangkan Model Pendampingan Desa Asimetris di Indonesia". Policy Paper. (Institute For Research And Empowerment (IRE), Yogyakarta).

Sarman, Mukhtar dkk, 2008. Program Pemberdayaan Masyarajat Berbasis LERD: Peluang Kalimantan Selatan (Pusat Kajian Kebijakan dan Pembangunan Daerah Universitas Lambung Mangkurat dan Pemerintah Provinsi Kalimantan Selatan).

Sarman, Mukhtar, 2009. Kolaborasi Pemerintah, Swasta \& Komunitas: Catatan dari Miyazaki. (Pusat Kajian Kebijakan dan Pembangunan Daerah Universitas Lambung Mangkurat, Banjarmasin).

Sarman, Mukhtar, 2017. Studi Pendahuluan: Hambatan Struktural Implementasi Kebijakan Dana Desa: Kasus Kecamatan Gambut. (Pusat Kajian Kebijakan dan Pembangunan Daerah Universitas Lambung Mangkurat, Banjarmasin).

Sarman, Mukhtar dan Purwanto, 2017. Transparansi Pengelolaan Dana Desa dalam Pelaksanaan Pembangunan Infrastruktur di Desa Malintang, Kabupaten Banjar. (Fisip Unlam, Banjarmasin).

Sarman, Mukhtar dan Fikri Jamaluddin Wahid, 2017. Implementasi Rencana Penggunaan Dana Desa di Kecamatan Gambut. (Fisip Unlam, Banjarmasin).

Sekarsita, Septina, 2017. Akuntabilitas Pengelolaan Keuangan Desa: Kasus Desa Bawahan Selan, Kabupaten Banjar. (Tesis pada Program Magister Sains Administrasi Pembangunan Universitas Lambung Mangkurat, Banjarbaru).

Sega, Ndione Joseph \& Suzuki Kanichiro, 2018. "The OVOP as a Tool to Develop Small and Medium-Size Enterprises: Insights from OVOP Enterpreneurial Experience in Senegal”. International Journal of Education and Research Vol. 6 No. 3, March.

Shinohara, Fumio, 1998. "Perspektif on Private Finance Initiative (PFI) in Japan", NLI Research Institute 1998 No.117.

Sofianto, Arif, 2017. "Kontribusi Dana Desa terhadap Pembangunan dan Pemberdayaan Masyarakat di Kebumen dan Pekalongan". Matra Pembaruan 1 (1): 23-32.

Syakriah, Siti, 2017. AkuntabilitasPengelolaan Dana Desa: Kasus Desa Tarung Manuah, Kabupaten Kapuas. (Tesis pada Program Magister Sains Administrasi Pembangunan Universitas Lambung Mangkurat, Banjarbaru).

Takao, Yasuo, 2007. Reinventing Japan: From Merchant Nation to Civic Nation. (Palgrave MacMillan, New York).

Turner, Sarah et.al., 2015. Frontier Livelihoods: Hmong in the Sino-Vietnemese Borderlands. (University of Washington Press, Seattle and London).

Utama, Kiki Yanita Budi, 2017. Kapasitas Pemerintah Desa Dalam Pengelolaan Dana Desa di Desa Caturtunggal, Kecamatan Depok, Kabupaten Sleman, Yogyakarta. (Tesis Magister Administrasi Publik Fakultas Ilmu Sosial dan Ilmu Politik Universitas Gadjah Mada, Yogyakarta).

Yoseph, Yetro M., 2018. Efektivitas Penggunaan Dana Desa: Studi Kasus Peranan Kepemimpinan Kepala Desa dalam Perencanaan Pembangunan di Desa Mangkahui, Kecamatan Murung, Kabupaten Murung Raya. (Tesis pada Program Magister Sains Administrasi Pembangunan Universitas Lambung Mangkurat, Banjarbaru). 